\title{
Estabelecimento in vitro de explantes de três cultivares de bananeira
}

\author{
Explants establishment in vitro of three banana cultivars \\ Silvia Nietsche ${ }^{1 *}$ Sandra Vanessa Marques ${ }^{2}$ Marlon Cristian Toledo Pereira $^{1}$ \\ Bárbara Salles² Adelica Aparecida Xavier André Cabral França² \\ Cynthia de Lima ${ }^{2}$ Lucivânia Sanguinette Silva ${ }^{2}$
}

\begin{abstract}
- NOTA -
RESUMO

O objetivo do presente trabalho foi avaliar dois protocolos de desinfestação na micropropagação em três cultivares de bananeira. Utilizaram-se mudas das cultivares de bananeira Prata Anã, FHIA 18 e SH3640. Os protocolos 1 e 2 de desinfestação (Des. 1 e Des. 2) foram realizados utilizando-se os seguintes produtos: solução fungicida de Derosol, álcool comercial, solução de hipoclorito de sódio e

in their concentration in every one of the protocols. The evaluations for contamination rate were taken daily by means of the total number of contaminated and non-contaminated tubes. A random block design in a factorial scheme with four repetitions was used. Exclusively bacteria had caused all contamination. Independently of the used treatment the contamination levels had been up to $29 \%$ for all the three cultivars tested. These results indicate the necessity of adjusting the new methodologies of asepses of banana explants.
\end{abstract} de hipoclorito de cálcio e tween 20, apresentando variações na concentração dos produtos em cada um dos protocolos. As avaliações para a porcentagem de contaminação foram realizadas diariamente por meio do número total de tubos contaminados e não contaminados. O delineamento foi em blocos casualizados, com quatro repetições, em um sistema fatorial. As contaminações que ocorreram foram causadas exclusivamente por bactérias. Independentemente do tratamento utilizado, os índices de contaminação foram superiores a $29 \%$ para as três cultivares testadas. Estes resultados indicam a necessidade de adequar novas metodologias de assepsias de explantes de bananeira.

Palavras-chave: Musa spp., micropropagação, contaminação.

\section{ABSTRACT}

The purpose of this work was to evaluate two protocols of disinfestations in the micropropagation on young plants of three banana cultivars: Prata-Anã, FHIA 18 and SH3640. Protocols 1 and 2 of disinfestations (Dis. 1 and Dis. 2) were carried out using the products: fungicidal solution of Derosol, commercial alcohol, solution of sodium hypo chlorite and calcium hypo chlorite and tween 20 , presenting variations
Key words: Musa spp., micropropagation, contamination.

A produção mineira de bananeira ocupa a quarta colocação no cenário nacional, com $6,7 \%$ do total produzido. O Norte de Minas Gerais destaca-se como uma das principais regiões produtoras dessa cultura, adotando alta tecnologia de produção e obtendo altas produtividades. Essa resposta deve-se principalmente às condições edafoclimáticas, como alta temperatura, média anual de $28^{\circ} \mathrm{C}$ e baixa umidade relativa, média de $65 \%$, associada à prática da irrigação (SOUTO et al., 1999). Tendo em vista que o sistema de propagação convencional in vivo é lento e possui baixo rendimento, tem-se observado que a adoção da micropropagação é uma das melhores alternativas (SOUZA et al., 1999). As principais vantagens deste método são a alta taxa de multiplicação em comparação aos métodos tradicionais e a alta qualidade

\footnotetext{
${ }^{1}$ Departamento de Ciências Agrárias, Universidade Estadual de Montes Claros (UNIMONTES), Av. Reinaldo Viana, 2630, Caixa Postal 91, 39440-000, Janaúba, MG, Brasil. E-mail: silvia.nietsche@unimontes.br. Autor para correspondência*.

${ }^{2}$ Curso de Agronomia da UNIMONTES. Av. Reinaldo Viana, 2630, Caixa Postal 91, 39440-000, Janaúba, MG, Brasil.
} 
fitossanitária das mudas (OLIVEIRA \& SILVA, 1997). O aprimoramento constante dos processos de multiplicação in vitro e o controle de qualidade das mudas, aliado à redução de custos, têm sido essenciais para a sua aceitação no mercado (ASSIS et al., 2000). As contaminações bacterianas são mais drásticas e trazem duas conseqüências básicas: a primeira é a perda de tempo e de recursos financeiros ou genéticos pela eliminação de frascos contaminados, e a segunda é o risco de contaminação de outras plantas (LOPES, 1988).

O objetivo do presente trabalho foi avaliar dois protocolos de desinfestação na micropropagação de mudas de bananeira das cultivares comerciais Prata Anã, FHIA 18 e SH3640.

Mudas das cultivares Prata Anã, FHIA 18 e SH3640 foram obtidas dos matrizeiros da UNIMONTES e da Embrapa, localizados nos municípios de Janaúba e Nova Porteirinha, região Norte de Minas Gerais. Foi realizada a limpeza mecânica dos explantes, removendose parte dos rizomas e pseudocaules até o tamanho aproximado de $5 \mathrm{~cm}$ de altura por $1,5 \mathrm{~cm}$ de diâmetro. Nessa etapa, os explantes de cada cultivar foram separados e, de forma individualizada, foram aplicados os dois protocolos de desinfestação. A metodologia 1 (Des. 1) de desinfestação foi realizada imergindo os explantes em solução fungicida, de Carbendazin (Derosol p.a.) a 3,3\% por 20min, em álcool comercial (92,8\%) por 60 segundos, seguindo-se de agitação por 20min com solução de hipoclorito de sódio na concentração de (2\% PV), constituindo o primeiro tratamento. No segundo tratamento (Des. 2), os explantes foram lavados com água destilada adicionada de $2 \%$ de detergente, em seguida imersos em solução fungicida de Derosol a 6,6\% por 20min em, álcool, na concentração de $70 \%$, por $5 \mathrm{~min}$, seguindo-se de agitação por 25min, com hipoclorito de cálcio (2\% PV) adicionado de três gotas de tween 20 para um litro de solução. Após a aplicação dos dois protocolos, realizou-se a tríplice lavagem dos explantes em água deionizada e esterilizada. O estabelecimento do material (subcultivo zero) foi realizado em meio nutritivo MS (MURASHIGE \& SKOOG, 1962), suplementado com 7mg. $\mathrm{L}^{-1}$ de 6-Benzilaminopurine (6-BAP). As características avaliadas foram: comprimento do explante, porcentagem de contaminação e o tipo de contaminante. O delineamento foi em blocos casualizados, com quatro repetições. Os tratamentos foram dispostos em esquema fatorial 3x2, constituído das cultivares de bananeira (Prata Anã, FHIA 18 e SH 3640) e de duas metodologias de assepsia. A análise estatística foi realizada por meio de análise de variância, sendo os efeitos dos tratamentos comparados pelo teste Tukey, em nível de 5\% de probabilidade.
Não foram detectadas interações significativas entre os métodos de assepsia e os cultivares avaliados. Ao final da fase de estabilização (subcultivo zero), foi obtido um total de 37,5\% de tubos contaminados para todas as cultivares avaliadas. Estes resultados confirmam os de OLIVEIRA \& MACHADO (1997), que observaram taxas de contaminação de até $61,4 \%$ durante a fase de estabelecimento. Na fase de estabelecimento in vitro dos explantes de bananeira, ocorrem taxas mais elevadas de contaminação do que nas fases de multiplicação e enraizamento dos brotos (WONG, 1986; ANGARITA\& PEREA, 1991; OLIVEIRA \& SILVA, 1997). Para a característica porcentagem de contaminação dos explantes de bananeira das cultivares Prata-Anã, FHIA-18 e SH-3640, foram detectadas diferenças significativas, com valores médios de $33,3 \%$, $45,8 \%$ e $29,2 \%$, respectivamente, independentemente do protocolo de assepsia utilizado (Tabela 1). Em relação aos dois protocolos utilizados, sugere-se que a utilização do álcool 92,8 GL e o uso do hipoclorito de sódio poderão ser os responsáveis pela menor contaminação observada nas cultivares, quando empregado o método 1. Estudos indicam que o hipoclorito de cálcio é menos tóxico aos tecidos do que o hipoclorito de sódio (GRATTAPAGLIA \& MACHADO, 1990). A concentração de etanol a 70\% deve ser utilizada, pois concentrações superiores podem causar rápida desidratação dos tecidos, apesar de VUYLSTEKE \& DE LANGHE (1985) não terem observado desidratação com a de 95\%. Das metodologias testadas no presente trabalho e aplicadas nas três cultivares, destaca-se o efeito do fungicida, por ter sido eficiente, não sendo detectado nenhum tipo de contaminação por meio de fungos. OLIVEIRA

Tabela 1 - Porcentagem de contaminação e classificação das bactérias em explantes de bananeira das cultivares Prata Anã, FHIA-18 e SH-3640, sob dois métodos de assepsia, UNIMONTES, Janaúba, 2004.

\begin{tabular}{|c|c|c|c|}
\hline \multirow{2}{*}{ Método de Assepsia ${ }^{2}$} & \multicolumn{3}{|c|}{ Porcentagem de contaminação (\%) } \\
\hline & Prata Anã & FHIA 18 & SH 3640 \\
\hline Des. 1 & $33,33^{1} \mathrm{~b} \mathrm{~A}$ & 45,83 a $A$ & 29,17 с A \\
\hline Des. 2 & 33,33b A & 45,83 a $\mathrm{A}$ & 29,17 с A \\
\hline Classificação das bactérias & Prata Anã & FHIA 18 & SH 3640 \\
\hline Gram + & $37,51 \mathrm{c} \mathrm{B}$ & 70,00 a $A$ & 42,86 b B \\
\hline Gram - & $62,50 \mathrm{a} A$ & 30,00 с B & 57,14 b A \\
\hline
\end{tabular}

${ }^{1}$ Médias seguidas da mesma letra minúscula nas colunas e de maiúscula nas linhas, dentro da mesma característica, não diferem entre si a $5 \%$ de probabilidade pelo teste de Tukey.

${ }^{2}$ (Des.1) método de assepsia 1, (Des.2) método de assepsia 2. 
et al. (2000), avaliando dois protocolos de desinfestação para a cultivar Pioneira, observaram apenas contaminações de origem bacteriana. Segundo LEIFERT et al. (1994), os principais gêneros de fungos têm sido o Penicillium, Cladosporium, Aspergillus, Botrytis, Alternaria e Fusarium. BORGES et al. (1997) sugerem que o pré-tratamento de matrizes é determinante para a redução da porcentagem de contaminação e não o tratamento de desinfestação. Os resultados apresentados indicam maiores porcentagens de bactérias do tipo Gram negativa nas cultivares Prata Anã e SH3640, com valores de $62,5 \%$ e $57,1 \%$, respectivamente (Tabela 1 ). Já para a variedade FHIA-18, grande parte das bactérias detectadas foi do tipo Gram positiva. As bactérias Gram positivas são do tipo não-fitopatogênicas e são freqüentemente encontradas no sistema digestivo do próprio manipulador. Pode-se então atribuir a ocorrência dessas contaminações à manipulação dos explantes durante a repicagem. Bactérias do gênero Bacillus são bastante tolerantes ao calor, podendo os esporos resistir a temperaturas de mais de $100^{\circ} \mathrm{C}$ e a tratamentos com álcool e hipoclorito de cálcio ou sódio (LEIFERT et al., 1994), sendo que os principais gêneros de bactérias fitopatogênicas são: Xanthomonas, Pseudomonas, Erwinia, Corynebacterium e Agrobacterium. Os resultados do presente trabalho indicam que o método de assepsia 1 reduziu significativamente a porcentagem de contaminação nas diferentes cultivares de bananeira testadas. Portanto, a utilização do fungicida Carbendazin (3,3\%), álcool comercial $(92,8 \%)$ e o uso do hipoclorito de sódio (2\%PV) são agentes eficientes no controle de fungos e bactérias em explantes de bananeira; entretanto, ajustes nas concentrações e tempos de imersão dos explantes devem ser realizados, bem como a possibilidade de adicionar novos agentes sanitizantes ao protocolo, com objetivo de reduzir os problemas com perdas devido às contaminações nos explantes de bananeiras.

\section{REFERÊNCIAS}

ANGARITA, A.; PEREA, M. Micropropagacion de plátanos y bananos. In: ROCA, W.M.; MROGINSKI, L.A. (Eds). Cultivo de tejidos em la agricultura. Cali: CIAT, 1991. p.495-512. ASSIS, M. et al. Micropropagação de plantas: histórico de uma empresa comercial. Informe Agropecuário, v.21, n.204, p.124-126, 2000.

BORGES, A.L. et al. O cultivo da banana. Cruz das Almas: EMBRAPA-CMPMF, 1997. 109p. (Circular técnica, 27).

GRATTAPAGLIA, D.; MACHADO, M.A. Micropropagação. In: TORRES, A.C.; CALDAS, L.S. (Editor). Técnicas e aplicações da cultura de tecidos de plantas. Brasília: ABCTP/ Embrapa-CNPH, 1990. p.99-169.

LEIFERT, C. et al. Ecology of microbial saprophytes and pathogens in tissue culture and field grown plants; reasons for contamination problems in vitro. Critical Reviews in Plant Science, v.13, n.2, p.139-183, 1994.

LOPES, C.A. Contaminações bacterianas em cultura de tecidos. ABCTP Noticias, n.13, p.35-40, 1988.

MURASHIGE, T.; SKOOG, F. A revised medium for rapid growth and bioassays with tobacco tissue cultures. Physiology Plant, v.15, p.473-497, 1962.

OLIVEIRA, R.P.; MACHADO, C.L. Avaliação de protocolo de micropropagação massal em bananeira do subgrupo Prata (Musa spp., grupo AAB). Revista Agropecuária de Fruticultura, v.19, n.2, p.415-226, 1997.

OLIVEIRA, R.P.; SILVA, S.O. Avaliação da micropropagação comercial em bananeira. Pesquisa Agropecuária Brasileira, v.32, n.4, p.415-420, 1997.

OLIVEIRA, R.P. et al. Efeito da desinfestação e do uso de meios indicadores de contaminação na micropropagação de bananeira. Revista Brasileira de Fruticultura, v.22, n.1, p.57-61, 2000.

SOUTO, R.F. et al. Novas perspectivas em sistemas de implantação, condução e praticas de manejo da bananeira. Informe Agropecuário, v.20, n.196, p.10-15, 1999.

SOUZA, A.S. et al. Propagação. In: ALVES, E.J. (Org). A cultura da banana: aspectos técnicos, socioeconômicos e agroindustriais. Brasília: Embrapa-SPI/ Cruz das Almas: Embrapa-CNPMF, 1999. p.157-195.

VUYLSTEKE, D.; DE LANGHE, E. Feasibility of in vitro propagation of bananas and plantains. Tropical Agriculture, v.62, n.4, p.323-328, 1985.

WONG, W.C. In vitro propagation of banana (Musa spp.): initiation, proliferation and development of shoot-tip cultures on defined media. Plant Cell, Tissue and Organ Culture, v.6, n.2, p.159-166, 1986. 